\title{
WISATA KONVENSI : POTENSI GEDE BISNIS BESAR
}

\author{
Tri Nugroho \\ Dosen Sekolah Tinggi Pariwisata AMPTA Yogyakarta
}

\begin{abstract}
MICE (Meeting, Incentive, Conference, Exhibition) in this time still represent the potential market of tourism in Yogyakarta. At the moment more's a lot of activity of MICE performed inYogyakarta, is so that expected in a period to coming Yogyakarta become the target of MICE after Bali.

With the existence of the growth wisata MICE, hence hotel in Yogyakarta of both for have there is and also which in the process of out for development make the meeting room ( Ballroom) which can accomodate until 2.500 visitor

Some hotel ready to for example Prodigal of Ambarruko Hotel, Sahid Rich Hotel, propose the readily Tentrem Hotel bicaming Yogyakarta as town of target MICE, with the goals 65\% activity MICE and 35\% guest from Travel Agent (Kompas com. 28 June 2014).
\end{abstract}

Keywords: MICE, Hotel, Tourism Service, MICE School.

\section{PENDAHULUAN}

Sampai tahun 1999 sektor pariwisata Indonesia masih berkutat dengan masalah fisi dan misi, strategi pemasaran serta target peraihan devisa tertinggi dan terendah dari wisatawan manca Negara yang berkunjung ke Indonesia.Sektor pariwisata Indonesia belum menyentuh persoalan yang sedang actual di Negara-negara lain yang lebih maju dalam bidang pariwisata. Mengapa demikian?. Sejak tahun 1980-an Negaranegara yang sudah maju dalam industry, perdagangan dan bisnis multi nasional, baik didunia Eropa, Amerika maupun negeri Timur (Jepang, Kore Selatan, Taiwan, Hongkong termasuk Australia di Selatan) telah mengembangkan satu bentuk baru dalam dunia pariwisata yaitu Wisata Konvensi atau Convention tourism.

Dewasa ini tumbuh keinginan untuk menggabungkan unsur kegiatan wisata dengan kegiatan bisnis asosiasi atau korporasi. Tujuannya adalah memajukan manajemen asosiasi dan korporasi mengembangkan profesionalisme, meningkatkan kecanggihan pemasaran dan penjualan, mengembangkan jasa pelayanan dan sikap pelayanan itu sendiri, menanggapi isu-isu industry pada umumnya, mencari peluang bisnis baru. Caranya dengan menyelenggarakan atau berpartisipasi dalam berbagai jenis pertemuan (meetings), konvensi dan konperensi, pameran, expo, trade fair, seminar, lokakarya (workshop), pelatihan dan pendidikan (training \& education), peluncuran produk baru (product launcing), perjalanan incentive dan lain-lain.

Pertemuan tersebut bisa dilaksanakan di suatu kota, resort pantai, pegunungan dan sebagainya yang memiliki tempat (venue) untuk kegiatan program-program tersebut, seperti pusat-pusat konvensi/konperensi, balai sidang/balai kota, aula universitas, kapal pesiar, hotel-hotel besar (bintang 4-5). 
Dalam pertemuan itu mereka bisa menyatakan apa yang mereka sedang pikirkan, rasakan dan mau melakukan dengan cara : berbicara, mengemukakan gagasan, menyatakan harapan, menyampaikan rasa cemas, meraih simpati dan dukungan, memperoleh kesempatan untuk maju dalam lingkungan, keadaan, situasi yang: ekonomi dan social maju, iklim dan cuaca nyaman, menyegarkan, rasa aman dan menyenangkan, masyarakat ramah dan bersahabat, jasa pelayanan professional, entusiasme penyelenggaraan kegiatan program.

Disebut sebagai wisata konvensi karena pertemuan itu didukung oleh perangkatperangkat paket kemasan tour\&travel menuju obyek-obyek daya tarik wisata dengan kandungan indahnya panorama, seni budaya etnis, benda-benda sejarah peninggalan arkeologi, adat-istiadat kebiasaan masyarakat setempat, rekreasi dan hiburan, petualangan, kompetisi olah raga, berbagai kegiatan keramaian (events).

Negara-negara Eropa, dimana masyarakatnya merupakan wisatawan prospektif bagi Negara-negara berkembang yang menggalakkan industry pariwisata, telah membuktikan betapa pesatnya pertumbuhan industry wisata konvensi ini secara signifikan bagi kota, daerah, propinsi atau Negara bagian yang memiliki daya pikat. Karena itu, hotel-hotel besar dipacu untuk memiliki seorang Manajer Konvensi (Convention Manager) atau coordinator konvensi (convention coordinator), khusus menangani tugas-tugas pekerjaan bisnis wisata konvensi.

IACVB : (International Association of Convention and Visitor Bureaus), IAPCO (International Association of Professional Congress Organization, UIA (Union of InternationalAssociation), EFCT (European Federation of Conference Towns), AIPC (Association Internationale des Palais de Congres, AACVB (Asian Associastion of Convention and Visitor Bureaus; mengaku betapa pesatnya kemajuan wisata konvensi. Hal ini diakibatkan oleh makin maraknya kegiatan program-program persidangan konvensi/kongres diselenggarakan, sehingga spectrum industry wisata konvensi ini semakin melebar luas ke berbagai kota, daerah, propinsi, Negara bagian atau nation yang memiliki daya pikat, unique and fascinating. Sebab, dunia kini adalah dunia yang bergerak, mengadakan perjalanan: The world is now traveling!

Dengan perkembangan wisata konvensi ini sudah waktunya bagi Indonesia berbenah diri untuk mampu bersaing dengan Negaranegara yang telah maju dalam bidang ini. Kendati terlambat tetapi Indonesia mempunyai banyak hal untuk dijual yang tidak dimiliki oleh Negara lain. Potensi yang dimiliki Indonesia janganlah tinggal potensi yang terkubur untuk selama-lamanya. (Nyoman S Pendit 1999, Wisata Konvensi, Potensi Gede Bisnis Besar).

\section{PEMBAHASAN}

\section{Konvensi}

\section{Arti Konvensi.}

Istilah Konvensi pada awalnya dimengerti sebagai suatu kegiatan yang menyenangkan bagi banyak orang ketika sedang berkumpul untuk suatu tujuan tertentu diantara mereka sendiri.Banyak pengusaha hotel kecil pada umumnya mempertanyakan : Apa Konvensi itu?. Sebaliknya bagi mereka yang sudah berpengalaman mengelola hotel besar, istilah Konvensi merupakan sebuah bisnis yang potensial bila dikaitkan dengan industri pariwisata. Konvensi adalah pertemuan sekelompok orang yang secara bersama-sama bertukar pikiran, pengalaman dan informasi melalui pembicaraan terbuka, saling siapuntukmendengardandidengar,serta mempelajari, mendiskusikan kemudian menyimpulkan topik-topik yang dibahas 
dalam pertemuan dimaksud. Kelompok ini bisa terdiri dari 10 orang atau lebih.

Secara lebih konkrit pemerintah melalui keputusan Menteri Pariwisata Pos dan Telekomunikasi No.KM 108/HM.703/ MPPT-91 merumuskan : Kongres, Konferensi, atau Konvensi merupakan suatu kegiatan berupa pertemuan sekelompok orang (negarawan, usahawan, cendekiawan dan sebagainya) untuk membahas masalah-masalah yang berkaitan dengan kepentingan bersama.

Selanjutnya dalam UU Kepariwisataan RI No. 10 tahun 2009 Bab VI pasal 14 (1) Usaha pariwisata meliputi, antara lain: daya tarik wisata, kawasan pariwisata, jasa transportasi wisata, jasa perjalanan wisata, jasa makanan dan minuman, penyediaan akomodasi, penyelenggaraan kegiatan hiburan dan rekreasi, penyelenggaraan pertemuan, perjalanan insentif, konferensi, dan pameran, jasa informasi pariwisata, jasa konsultan pariwisata, jasa pramuwisata, wisata tirta; dan SPA.

Sebagaitolokukurpedoman pelaksanaan suatu konvensi, pemerintah Indonesia mempergunakan Keputusan Menteri Pariwisata dan Ekonomi Kreatif nomor 28 Tahun 2014, tentang Standar Usaha Jasa Pertemuan, Perjalanan Insentif, Konferensi dan Pameran, Bab 1 pasal 1 yang berbunyi:

a. Usaha Pariwisata adalah usaha yang menyediakan barang dan/atau jasa

b. Usaha jasa penyelenggaraan Pertemuan, Perjalanan Insentif, Konferensi dan Pameran, yang selanjutnya disebut Usaha jasa penyelenggaraan PIKP, adalah pemberian jasa bagi suatu pertemuan sekelompok orang, penyelenggaraan perjalanan bagi karyawan dan mitra usaha sebagai imbalan atas prestasinya, serta penyelenggaraan pameran dalam rangka penyebarluasan informasi dan promosi suatu barang dan jasa yang berskala nasional, regional, dan internasional.

\section{Pameran.}

a. Pameran merupakan suatu kegiatan untuk menyebar luaskan informasi dan promosi yang ada hubungannya dengan penyelenggaraan konvensi atau yang dikaitkan dengan pariwisata.

\section{b. Usaha Jasa Konvensi, perjalana Incentive dan Pameran} merupakan usaha dengan kegiatan pokok memberi jasa pelayanan bagi suatu pertemuan sekelompok orang (negarawan, uisahawan, cendekiawan dan sebagainya) untuk membahas masalah-masalah yang berkaitan dengan kepentingan bersama.

c. Izin usaha adalah izin yang diberikan oleh Direktur Jendral untuk menyelenggarakan usaha jasa Konvensi, perjalanan incentive dan pameran.

Pameran sebagai usaha jasa Pariwisata.

Pameran yang dikaitkan dengan industri pariwisata dalam bahasa Inggris disebut dengan berbagai istilah tergantung pada jenis kegiatan pameran yang diselenggarakan, seperti : Exhibition, Expo atau Exposition, Industrial show, Trade Fair, Trade Show, Scientificl technical atau Professional/scientific exhibition.

Pakar pameran seperti Hale N.Tongren dan James P. Thomson, mendefinisikan Industrial Show ( pameran industry ) adalah kegiatan pameran yang dimanfaatkan oleh 


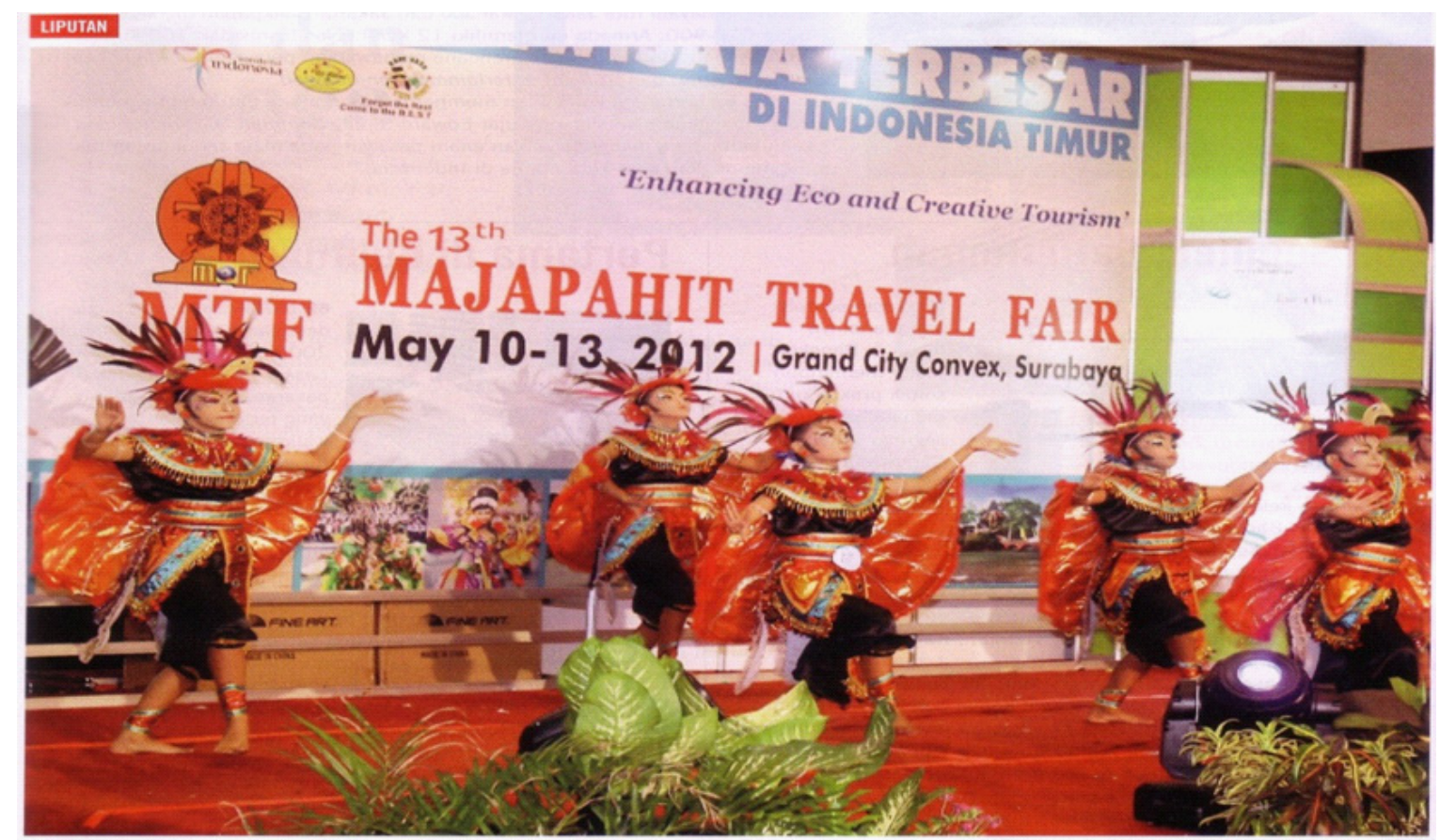

perusahaan-perusahaan pembuat alatalat dan produk-produk tertentu untuk menggelar hasil karyanya bagi umum dan perusahaan lain yang berminat untuk membelinya. Trade Show (pameran dagang) adalah pameran untuk berdagang. Pembeli datang berkunjung ke pameran ini untuk membeli produk demi kebutuhan sendiri atau diperjual belikan kembali dalam jumlah banyak.

Professional or scientific exhibition (pameran ilmiah atau professional) adalah pameran yang dikaitkan dengan persidangan kelompok professional, guru, ilmuwan,dan mereka yang merupakan pemakai akhir (end users) dari produk atau jasa pelayanan yang digelar pada pameran ini. Kegiatan Pameran (Exhibition) dalam pengertian umum adalah merupakan salah satu cara atau media penyebaran informasi, perkenalan sekaligus pemasaran suatu produk, baik berbentuk gagasan maupun barang.

\section{M I C E}

MICE adalah kegiatan Konvensi, Perjalanan Incentive dan Pameran dalam industry pariwisata. Apa yang dimaksud dengan MICE ?. Secara tehnis MICE digolongkan kedalam industry pariwisata.Dalam istilah Indonesia MICE diartikan sebagai wisata Konvensi, dengan batasan Usaha Jasa Konvensi, perjalanan incentive dan pameran merupakan usaha dengan kegiatan memberi jasa palayanan bagi suatu pertemuan sekelompok orang (negarawan, usahawan, cendekiawan dan sebagainya) untuk membahas masalahmasalah yang berkaitan dengan kegiatan usaha pariwisata lain, seperti transportasi, akomodasi, hiburan, perjalanan pra dan pasca konferensi (pre and post conference tours).

\section{M = Meeting}

Adalah istilah bahasa Inggris yang berarti Rapat, Pertemuan atau Persidangan adalah merupakan hal yang lazim bahwa rapat, pertemuan atau persidangan ini diselenggarakan oleh kelompok orang yang bergabung dalam suatu asosiasi, perkumpulan atau perserikatan.

\section{I $=$ Incentive.}

Istilah incentive, oleh pemerintah 
Indonesia seperti tercantum dalam UU No.9 tahun 1990 tentang kepariwisataan diartikan sebagai perjalanan Insentif. Selanjutnya perjalanan insentif ini ditentukankegiatanusahanyadalamsurat Keputusan Memparpostel No.KM.108/ HM.703/MPPT-91, bab 1 pasal 1 ayat $b$ yang merumuskan perjalanan insentif merupakan suatu kegiatan perjalanan yang diselenggarakan oleh suatu perusahaan untuk para karyawan dan mitra usaha sebagai imbalan penghargaan atas prestasi mereka dalam kaitan penyelenggaraan konvensi yang membahas perkembangan kegiatan perusahaan yang bersangkutan.

\section{$\mathrm{C}=$ Converence.}

Istilah converence diterjemahkan dengan Konperensi dalam bahasa Indonesia yang mengandung pengertian yang sama. Dalam kaitannya dengan MICE, surat keputusan Menteri Pariwisat Pos dan Telekomunikasi nomor KM.108/ HM.703/MPPT-91 menyebutkan bahwa konferensi, kongres atau konvensi merupakan suatu kegiatan berupa pertemuan sekelompok orang (negarawan, usahawan, dan sebagainya) untuk membahas masalah-masalah yang berkaitan dengan kepentingan bersama.

\section{$\mathbf{E}=$ Exhibition .}

Exhibition berarti pameran. Dalam kaitannya dengan industry pariwisata, pameran termasuk dalam bisnis wisata konvensi. Hal itu diatur dalam surat keputusan Memparpostel RI Nomor KM.108/HM.703/MPPT-91 bab 1 pasal 1c, yang berbunyi pameran merupakan suatu kegiatan untuk menyebar luaskan informasi dan promosi yang ada hubungannya dengan penyelenggaraan konvensi atau yang ada kaitannya dengan pariwisata.

\section{Memanfaatkan Potensi Industri MICE}

Di Surat Kabar Harian Kedaulatan Rakyat yang terbit pada tanggal 16 September 2014 memuat berita bahwa TCEB (Thailand Convention and Exhibition Bureau, organisasi public, menekankan meningkatnya kepentingan industry MICE dalam mendorong pertumbuhan dua Negara Ekonomi terbesar di ASEAN. Mengulangi kemitraan berkelanjutan Thailand dengan industri MICE di Indonesia, TCEB juga memperkenalkan paket promosi khusus bagi Indonesia yaitu Connect Businnes bagi event pemerintah dan Connect People bagi event convensi. Sebagai dua kekuatan ekonomi terbesar di ASEAN, Thailand dan Indonesia memiliki peluang unik untuk bekerjasama dalam memanfaatkan potensi transformasional industry MICE masing-masing.

TCEB berkomitmen untuk memfasitasi dan mendukung kerja sama antara pelaku industry MICE di ASEAN dan menciptakan peluang match making antara pihak terkait di Thailand dan Indonesia dengan memanfaatkan event pameran dan konvensi sebagai platform yang efektif dalam hal memperkuat perdagangan bilateral melalui pengembangan industry MICE.

Huubungan bisnis bilateral antara Thailand dan Indonesia telah berlangsung lama dan produktif. Thailand menempati peringkat sebagai mitra dagang ketiga terbesar Indonesia di kawasan ASEAN pada tahun 2013, dan angka perdagangan antara kedua Negara diperkirakan mencapai US $\$ .16$ miliar di tahun 2014. Hal tersebut menunjukkan hubungan industri MICE yang kuat. Indonesia secara konsisten berada di 10 besar pengunjung MICE ke Thailand, dan meningkat menjadi peringkat ke 6 di tahun 2013. (KR.Rsv). 


\section{Peluang Dibalik Ketimpangan}

\section{Lulusan sekolah MICE tidak melulu harus bekerja untuk Organizer. Kalangan korporasi juga membutuhkan kepiawaian mereka.}

Melalui tender, perusahaan dan kementrian menyewa Organizer untuk menggelar acara. Namun, siapakah orang yang mengurusi proses tender di perusahaan dan kementrian tersebut? Di sinilah terbuka peluang kerja bagi alumni kampus MICE!

Mahasiswa yang belajar di kampus MICE boleh berbesar hati karena posisi tawar mereka jauh lebih tinggi. Kebutuhan tenaga kerja di sector ini lebih besar dibandingkan pasokannya. Setiap tahunnya, sekolah tinggi yang memiliki jurusan MICE hanya mewisuda kurang dari 50 mahasiswa. Padahal jumlah lowongan kerjanya jauh lebih besar. Lowongan itupun bukan hanya datang dari PEO atau PCO. Kalangan korporasi kini makin sadar akan pentingnya memiliki SDM yang memahami seluk-beluk manajemen acara. Banyak perusahaan kini memiliki divisi khusus yang menangani kegiatan below the line (BTL). Tugasnya beragam, mulai dari menggelar tender acara hingga mengadakan acara secara mandiri, misalnya peluncuran produk dan konferensi pers. Saat ini baru sekitar 60\% yang benar-benar terserap ke perusahaan exhibition organizer atau conference organizer.

Menurut Jay M.S., mantan Kepala BTL \& Brand Activation Indosat, SDM yang piawai menyelenggarakan acaraacara MICE sangat dibutuhkan oleh korporasi. Keahlian mereka berguna untuk medongkrak pamor produk atau jasa yang ditelurkan perusahaan melalui rangkaian kegiatan brand activation.

Terbuka lebarnya peluang kerja di sector event inilah yang membuat minat menimba ilmu MICE terus menunjukkan grafik positif. Tingginya kebutuhan SDM MICE juga memicu kampus untuk berbenah. Program Vokasi Universitas Indonesia misalnya, telah memasukkan MICE dalam kurikulum perkuliahan sejak tahun 2002. Kami telah meluluskan sekitar 400 mahasiswa, dan saat ini berencana untuk membuat program D.IV MICE, kata Aris Miyati Nasution, Dosen Program Vokasi UI.

\section{Korporasi Menjadi Faforit.}

Berdasar hasil wawancara majalah VENUE dengan sejumlah mahasiswa D.IV MICE, minat kerja di perusahaan non MICE lebih tinggi daripada PEO (Professional Exhibition Organizer) atau PCO (Professional Convention Organizer). Alasannya bervariasi, mulai dari standar gaji hingga ritme kerja di perusahaan Organizer yang tidak teratur. Di perusahaan lain juga sudah ada profesi yang membutuhkan keahlian MICE, misalnya untuk penyelenggaraan acara atau brand activation. Lapangan pekerjaan untuk lulusan MICE ini memang luas, namun tentunya tugas mereka tetap terkait dengan penyelenggaraan acara .

Namun impian alumni sekolah MICE untuk berkarier di sector korporasi tidak semulus yang diharapkan. Pasalnya para korporasi itu biasanya mencari SDM MICE yang sudah berpengalaman.

Untuk mengatasi hal tersebut diatas maka perlu diatasi dengan system program magang di perusahaan Organizer. Selain itu mereka juga diberikan tugas akhir untuk menyelenggarakan acara MICE. Dalam tugas akhir itu mereka dituntut untuk mampu menyusun konsep acara, mencari sponsor dan peserta,hingga mengeksekusi acara. (Dikutip dari tulisan ARIA WICAKSANA di majalah VENUE No.84 Tahun ke 7 bulan Juni 
2014).

Berdasar paparan tersebut diatas, mampukah Sekolah Tinggi Pariwisata AMPTA membuka jurusan MICE sebagai pengganti Jurusan Usaha Wisata yang akan ditutup? Atau masuk program APHS (Ambarrukmo Palace Hotel School)? Hal ini merupakan tantangan yang perlu kita hadapi bersama-sama, sehingga apa yang tidak mungkin bisa menjadi kenyataan, apabila Tuhan ALLAH SWT meridhoinya, Amin ya Robbil Allamin.

\section{KESIMPULAN}

Bahwa dengan adanya perkembangan yang pesat di Indonesia tentang kegiatan Konvensi, hotel-hotel sekarang berlomba mengambilkeuntungan dariterselenggaranya wisata MICE.

Pada mulanya, penghasilan terbesar dari suatu hotel adalah hasil penjualan kamar (Room Sales), menyusul hasil penjualan dari Food\&Beverage, kemudian dari OOD (Other Operating Department). Sekarang terbuka kesempatan mendapatkan keuntungan dari adanya wisata MICE, yang ternyata bisa mendatangkan pengunjung yang lebih banyak, lama tinggal yang lebih lama dan pembelanjaan uang yang lebih besar. Hal ini sudah barang tentu akan memberikan penghasilan yang cukup besar bagi hotel-hotel.

\section{DAFTAR PUSTAKA}

Aria Wicaksana 2004 Majalah Venue No.84 Tahun 7, Juni 2014

Kompas .com 28 Juni 2014

Nyoman S Pendit, 1999 Wisata Konvensi, Potensi Gede Bisnis Besar PT Gramedia Pustaka Utama, Jakarta.

SKH Kedaulatan Rakyat Yogyakarta 2014 tanggal 16 September 2014 